\title{
Facts About Folate ${ }^{1}$
}

\author{
Linda B. Bobroff ${ }^{2}$
}

\section{Why do we need folate?}

Folate is one of the B vitamins. The synthetic form of this vitamin is folic acid. Folate helps make DNA and amino acids. DNA is the genetic material found in all cells of the body, and amino acids are the building blocks of proteins.

Everyone needs folate. It is especially important for women who can become pregnant. Pregnant and nursing women, growing children, and older adults also need plenty of folate.

\section{What happens if we don't get enough folate?}

Without folate, your body can't make DNA and amino acids. This is a concern for women who are pregnant and children, who are making new cells. Eating high-folate foods may reduce your chances of developing anemia, stroke, and cancer. Getting enough folate before becoming pregnant reduces a woman's risk of having a baby with certain birth defects.

\section{How much folate do we need?}

The recommended amounts for folate are given in dietary folate equivalents, or DFEs, which account for the difference in the amount of folate available for absorption between folate from food and synthetic folic acid. The following table lists recommended daily intakes of folate for adults and teens.

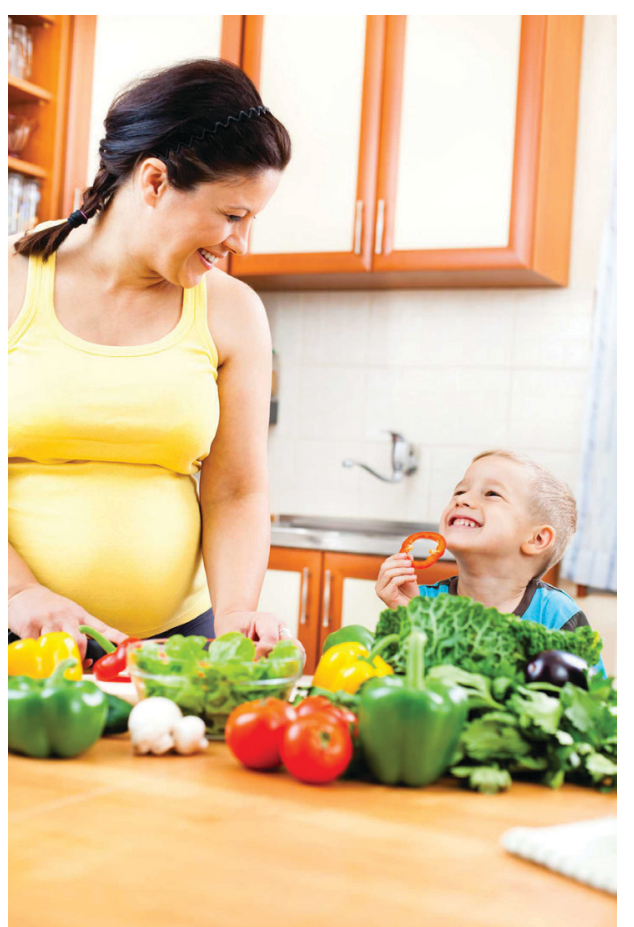

Figure 1. Pregnant women and children need to get adequate folate every day.

Credits: fotostorm

Table 1.

\begin{tabular}{|l|c|}
\hline \multicolumn{1}{|c|}{ Life Stage } & Folate (mcg DFE/day) \\
\hline Teens and adults & 400 \\
\hline Pregnant women & 600 \\
\hline \multicolumn{2}{|l|}{ Breastfeeding women } \\
\hline $\begin{array}{l}\text { mcg DFE = micrograms of dietary folate equivalents } \\
\text { Source: Otten, Hellwig, \& Meyers (2006) }\end{array}$ \\
\hline
\end{tabular}

1. This document is FCS8632, one of a series of the Department of Family, Youth and Community Sciences, UF/IFAS Extension. Original publication date March 2001. Revised February 2018. Visit the EDIS website at http://edis.ifas.ufl.edu.

2. Linda B. Bobroff, PhD, RDN, professor, Department of Family, Youth and Community Sciences; UF/IFAS Extension, Gainesville, FL 32611.

The Institute of Food and Agricultural Sciences (IFAS) is an Equal Opportunity Institution authorized to provide research, educational information and other services only to individuals and institutions that function with non-discrimination with respect to race, creed, color, religion, age, disability, sex, sexual orientation, marital status, national origin, political opinions or affiliations. For more information on obtaining other UF/IFAS Extension publications, contact your county's UF/IFAS Extension office. 


\section{How can we get enough folate?}

To get 400 mcg DFE every day, you can eat foods that are naturally high in folate. Some of the best food sources are green leafy vegetables, such as spinach, collards, and kale. Other foods that are high in folate are orange juice, legumes (dried beans and lentils), nuts, and peanuts.

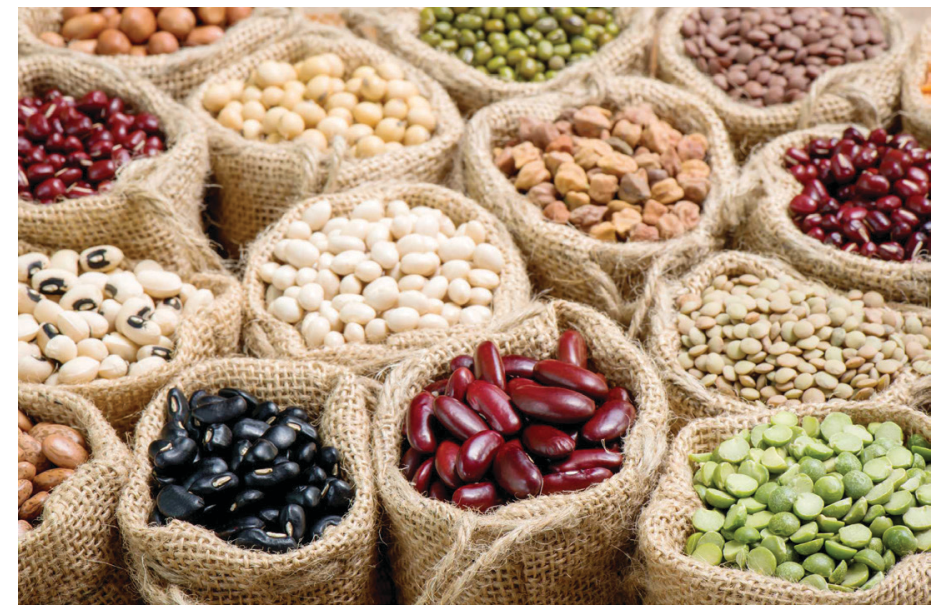

Figure 2. Dried beans, peas, lentils, and nuts are all good sources of folate.

Credits: Enrique Díaz/7cero

Getting enough folate is easy if you eat foods that are fortified with folic acid, such as fortified grain foods. Check food labels to see if folic acid has been added to other foods. Here is a sample ingredient list from a food label:

Table 2. Here are some foods and the amount of folate they contain.

\begin{tabular}{|l|c|}
\hline \multicolumn{1}{|c|}{ Food } & Folate (mcg DFE/serving) \\
\hline Fortified cereal, 1 serving & $100-600$ \\
\hline Spinach, frozen, $1 / 2$ cup cooked & 115 \\
\hline Peanuts, dry roasted, $1 / 2$ cup & 70 \\
\hline Romaine, 1 cup shredded & 65 \\
\hline Kidney beans, $1 / 2$ cup cooked & 115 \\
\hline Orange juice, $3 / 4$ cup & 40 \\
\hline Orange, 1 medium & 45 \\
\hline $\begin{array}{l}\text { mcg DFE = micrograms of dietary folate equivalents } \\
\text { Source: USDA (2016) }\end{array}$ \\
\hline
\end{tabular}

Ingredients: Apples, enriched wheat flour (contains niacin, reduced iron, thiamine mononitrate, riboflavin, and folic acid), partially hydrogenated soybean oil, water, sugar, modified food starch, salt, cinnamon, cornstarch.

\section{How should foods be prepared to keep the folate content?}

When cooking foods that contain folate, use as little water as you can and avoid overcooking. Steaming or cooking in a microwave minimizes folate loss for most foods.

\section{What about supplements?}

If you don't get enough folate from foods, you can take a multivitamin that contains folic acid. A folic acid supplement is recommended for people with a special need for folate. This includes all women who can become pregnant, who should get $400 \mathrm{mcg}$ of supplemental folic acid every day in addition to folate from various foods. To avoid getting too much folic acid, keep intake from fortified foods and supplements below $1,000 \mathrm{mcg} /$ day for adults and 800 $\mathrm{mcg} /$ day for teens between the ages of 14 and 18 .

\section{Where can I get more information?}

Your local UF/IFAS Extension Family and Consumer Sciences agent may have written information and nutrition classes for you to attend. In Florida, find your local UF/ IFAS Extension office at http://solutionsforyourlife.ufl.edu/ find-your-local-office/. Your doctor or a registered dietitian nutritionist (RD or $\mathrm{RDN}$ ) can also provide reliable information to you. Reliable nutrition information is available online at the following sites:

http://nutrition.gov

https://ods.od.nih.gov/factsheets/Folate-Consumer/

\section{References}

Otten, J. J., Hellwig, J. P., \& Meyers, L. D. (2006). Dietary Reference Intakes: The Essential Guide to Nutrient Requirements. Washington, D.C.: The National Academies Press.

USDA. (2016). USDA National Nutrient Database for Standard Reference, Release 28. Accessed on January 22, 2018. https://ods.od.nih.gov/pubs/usdandb/Folate-Food. pdf 